\title{
PPIF wt Allele
}

National Cancer Institute

\section{Source}

National Cancer Institute. PPIF wt Allele. NCI Thesaurus. Code C118235.

Human PPIF wild-type allele is located within 10q22-q23 and is approximately 8 kb in length. This allele, which encodes peptidyl-prolyl cis-trans isomerase $F$, mitochondrial protein, plays a role in the modulation of both protein folding and mitochondrial permeability transition pore-induced cell death. 